\title{
Transactional Reading Theory in Information Organization
}

\author{
Marek Nahotko \\ Institute of Information and Library Science \\ Jagiellonian University
}

\begin{abstract}
Purpose/thesis: The article is intended to present some opportunities to apply the text genres theory, transaction theory and cognitive schemata theory in the information organization. The text genre should be understood here as a mental schema developed and distributed as a result of repeatable transactions with the text. The bibliographic (catalog) record can be treated as a text of a specified genre, which enables the scientists to research the social transactions both between the text and the author (information organizer, librarian) and the text and the recipient (information system user, library). All research presented in the article may be helpful to describe changes in transactions related to the changes in information technologies.

Methods: The article contains the description of changes to the transactions of information organization resulting from the application of new information technologies, that is the transformation of bibliographic record text into cybertext and their genres into cybergenres.

Results and conclusions: Any changes to the technologies used in the information organization lead to the development and enhancement of the user's transactions with the text of the record in order to increase the search capabilities and simplify the methods of transaction implementation.

Originality/Cognitive value: The approaches presented in the article are based on the theories of: cognitive schemata (constructivism), text genres (Miller and Andersen) and transactions (Dewey, Rosenblatt), applied in the analysis of bibliographic (catalog) records, treated as texts built in a specified convention arising from the repeatable transactions between information organizers and users. This point of view helps place those texts in an appropriate place among texts present in the scientific discourse.
\end{abstract}

Keywords

Information organization. Theory of text genres. Transactional theory of reading.

Received: 3 November 2015. Revised: 14 December 2015. Accepted:20 December 2015.

\section{Introduction}

The fragmentation of modern science into the fields and narrow specializations results in the examination of a phenomenon or an object from various points of view and with the use of a number of methodologies and terminologies. This is the current situation in the field of information activities. Information science examines material, mostly written documents (Wojciechowski, 2014, 67), as the carriers of information that can be internalized by the user while being used (read). Pedagogy and psychology study individuals reading texts. In the first instance the matter of interest is, among others, the effectiveness of information 
retrieval, in the second instance it is the effectiveness of learning and reading processes. Differences arise in large part from the fact that information scientists, due to the nature of their discipline, work in direction from the general to the particular, from the general phenomena related to the knowledge and information resources to the detailed ones, while experts from other fields must operate in reverse - from the particular to the general (Capurro \& Hjørland, 2003, 389).

Information, internalized in the course of cognitive processes, becomes knowledge (Thellefsen et al., 2015, 523). The cognitive processes are communication processes, performed in the universe of discourse (a contextual framework) and in relation to the common experience that occurs between the information sender and the recipient, that is, two human beings. Moreover, these processes are the subject of research in many fields. As explained by Teun van Dijk, the majority of human knowledge is acquired and shaped by discourse, which is also one of its major verification criteria. The use of language in general, and the creation of discourse understanding in particular, are impossible without activating the vast resource of knowledge about the world (Dijk, 2014, 5). The quoted author mentions numerous disciplines dealing with these problems: epistemology, psychology and neuropsychology, sociology, anthropology, communication studies, organization studies, linguistics, semiotics and discourse studies. Information science is not listed there, but research on problems such as information needs and behaviour, various sources of information, their organization and their place in the knowledge society allows researchers to argue that the discipline can also be considered as one that studies knowledge and the processes of its creation and transmission. It is a part of a multidisciplinary framework, permitting integrated research on the methods of gathering, presuming, expressing and communicating externalized knowledge in different genres of spoken and written texts and cognitive communicative situations.

Interdisciplinarity can be defined as a dialogue, an exchange or confrontation of opinions and findings between several disciplines (Chanal, 2012, 401). One of the forms of interdisciplinary research is a study based on a theory developed in other discipline. It leads to a dialogue with the issues, concepts and methods of one or several disciplines in order to borrow or adopt some new elements or challenging parts of these fields to another discipline. This way, the information science research can benefit from the application of ideas and achievements of other disciplines, which in turn can increase the retrieval abilities of information systems used. In order to have impact on the research in other disciplines, information science should pursue issues that are seen as important by researchers in these disciplines and in addition are investigated with research traditions of these disciplines taken into account (Kock, 2009, 395). In this article the author intends to present some theories developed mostly in psychology, sociology and linguistics from the point of view of their use in information science research. The theories in question, though well established in the aforementioned disciplines, in the information science literature are new, in general, and in Polish literature of the field often are completely unknown. Their use is mainly related to the issues of information organization and knowledge processes, in particular to the studies on the use of metadata (metainformation ${ }^{1}$ ) in the light of selected psychological,

\footnotetext{
${ }^{1}$ Metadata is a generally used term, although information organizers produce documents descriptions, which contain metainformation rather, as described documents contain information.
} 
linguistic and sociological theories and concepts. These theories allow one to understand metadata records as texts, which are experienced by a person transacting with them and constructing their meaning to realize his/her information needs.

\section{The theory of cognitive schema, the theory of text genres, and the transactional reading theory}

The psychological theory of cognitive schemata is fundamental for all other theories discussed in this article. It was strongly influenced by the constructivist theory of learning (pedagogical constructivism ${ }^{2}$ ), in which special attention is paid to the active construction of knowledge by individuals. Despite many objections to social constructivism (Wilson, 2011, 57), the constructivist theory of learning becomes increasingly accepted, as it combines the best traditions of learning theories, from Socrates to Dewey, and the basic ideas expressed in the works of Piaget, Vygotsky and Bruner.

According to constructivism, learning is defined as the integration of new knowledge with the one already possessed by the individual. This integration requires active involvement in the process of acquiring new knowledge, which implies that knowledge is a construct created individually. Importantly, the information acquisition and new knowledge creation take place not only during textbooks studying - these processes are supported by natural abilities of the brain, and they are performed continuously throughout life, during which the individual organizes his/her own personal world. However, these processes occur in constant interaction with the environment and confrontation with the individual's mental states leading to the regular reconstruction of the individual's own vision of the world.

According to the theory of cognitive schemata, all acquired knowledge is organized in schemata, that is, the structures of knowledge represented in the memory of individuals (Sosińska-Kalata, 1999, 88). Schemata are created by people for everything that is in their surroundings (what they learn): people, places, objects, language, processes and skills (Tracey \& Morrow, 2012, 62). Each person has his/her own schemata, individually created and constantly modified: the knowledge structures are flexible and extensible. Schemata are individualized according to the acquired experience and "ideas" created on their basis (Pearson, 2009, 13).

From the point of view of language competences the theory of mental schemata is closely related to the theory of text genres. It is noticeable that schemata related to reading/ writing correspond to the text genres, or vice versa - the text genre is a kind of mental schema. This understanding of the text genre is close to its systemic-functional meaning, where the text genre is an organized, goal-oriented activity in which speaking (writing/ reading) persons are involved as members of a culture (Martin, 2001, 155). Each social activity requires the use of a genre. The similarity of so-understood genres to the schemata, as they are described by quoted Tracey and Morrow is clear. As Amy Devitt writes, the theory of schemata, allowing for the understanding of the complexity of the conventions used by people, is a precursor essential for the understanding of the genre conventions (Devitt, 1993, 584).

\footnotetext{
${ }^{2}$ Despite its use in pedagogy, the constructivism is not a theory of teaching, but the theory of cognition.
} 
The text genres research can be derived from antiquity (Gajda, 2009, 135). The 1980s witnessed so-called "rhetorical turn in studies of genres" (Auken, 2015, 156). It was a change in the definition of the basic characteristics of the genre; the utterance was replaced in this role by the function ${ }^{3}$. This means moving away from the understanding of the genre as primarily the content and form of utterance to its social function. This way two characteristics of the genres (the form and content, together constituting the utterance) were completed by the third one, that is, the function or action. It is worth noting that genres understood in such way are rarely used in the study of literary texts, rather they refer to so-called utilitarian texts.

That is Carolyn Miller's, one of the prominent authors promoting the change in rhetorical studies of genres, understanding of the genres - the move from the focus on the utterances to the identification of their functions in communication. Therefore Miller defined genre as

typed actions based on recurrent rhetorical situations (Miller, 1984, 159).

This means treating genres as communication activities performed between the author (creator) and the reader (receiver) in shared space of meaning and action (Andersen, 2015b,4).

Misha Vaughan and Andrew Dillon provide a definition, which is an extension of Miller's definition (Vaughan \& Dillon, 2006, 503). According to them, the genre is a class of communication events, which are characterized by having a common set of conventions and rules aimed at facilitating the interaction of communicating parties (users) by creating and handling (e.g. modifying) expectations in the community of creators (authors) and receivers (readers). This definition indicates that the level of uniformity of the concept in the user community can be studied both from the point of view of its physical manifestation users and from the point of view of social, historical and cultural meaning interpretation. However, apart from socio-cultural aspects of the use of text genres, there are also cognitive factors, the results of which are not only the communication aims of the community of discourse, but also the cognitive strategies used by the community members to achieve the objectives of communication taken into account (Bhatia, 1997, 629).

Two features of the text genres are particularly important as regards further considerations in this article. Firstly, genres are not immutable constructs; on the contrary, they are very dynamic phenomena. The reason for this has already been mentioned; mental schemata, and hence genres, are changing with every new experience. Each new text, created within a genre convention enhances or remodels the genre in some aspects, according to the knowledge of the author. Also, each reader in the act of reading transforms his/her social comprehension (understanding). Genre does not exist without its history, and the history grows with each new text referring to the rules of the genre. On the other hand, genres must form relatively permanent structures towards their usefulness in the act of communication (Bakhtin, 1986, 348). Some cultural aspects, like particular language use, also influence genre diversity (Wierzbicka, 1983, 136); the Polish conventions of the bibliographic description is slightly different genre than the English ones ${ }^{4}$.

\footnotetext{
${ }^{3}$ Auken states that the term "utterance" could be replaced by "text", but many linguistic expressions are oral, and other genres are not linguistic or are partially linguistic, so the term "utterance" includes more cases than "text".

${ }^{4}$ This is probably a reason for the need of a local adaptation of the ISBD rules, such as that made in Poland by M. Lenartowicz (1986).
} 
The second important aspect relates to the connectivity of genres. It rarely happens that a genre is used in total isolation from the other genres. Different genres coordinate jointly social activities or one genre activates the use of other ones in various systems of these activities (transactions) (Andersen, 2015b, 10). This feature is related to such concepts as the genre set, the system of genres and the repertoire of genres. The first concept was used by Amy Devitt in her work on intertextuality ${ }^{5}$ in tax accounting. A set of genres reflects the professional activity and social relations of specialists she described, that is, their occupational situation (Devitt, 1991, 340). It can help to define and stabilize the situation, since all members of the group using a given genre set share knowledge (similar mental schemata) on commonly used genres that constitute one set (Devitt, 1993, 581). The concept of the genres system was introduced by Charles Bazerman, who defined it as a group of interrelated genres interacting with each other in certain circumstances (conditions) (Bazerman, 1994, 97). It is a complete interaction (or rather transaction), the complete event, a set of social relationships, shown in the way in which they operate. The use of the genre system concept allows one to study methods of organizing textual knowledge-creating activities and dependences of these actions on texts, which are mediation tools for these activities. The repertoire of genres, according to Wanda Orlikowski and JoAnne Yates, is an analytical tool for studying the structures of communication practices within a given community (Orlikowski \& Yates, 1994, 541). Applying the concept of the genre repertoire means the transition from an individual standpoint on genres (used in the case of a set of genres) to a social perspective.

The last concept regarding genres connectivity is a group of genres. This concept is usually applied in the area of the text genres used in organizations, including libraries and other information systems. The genre group is a set of genres, potentially suitable for use in the writing/reading transactions typical for a given kind of organizations, from the set of which the genres useful and suitable for use in the communication situation of the organization are selected. Creation of an information system, especially its information organization systems from the point of view of genres used, involves making a choice of working genres from groups of genres. The selected genres best meet the communication needs and execution of transactions of the information system users. Each genre selected usually prevents the choice of other genres in the same group and limits the choice of genres from other groups. For example, within the group of genres aimed at subject cataloging onlyone of them must be selected (usually when designing the system), for example the subject headings vocabulary, which usually prevents the use of classification tables. This choice in turn affects the use of genres from other groups, for instance it defines the place of subject description in the bibliographic record. Subject headings are placed in specific fields of the MARC bibliographic record ${ }^{6}$.

The theory of mental schemata has been applied in the area of writing/reading and text perception by Louise Rosenblatt, who has developed the transactional theory since the 1970s

\footnotetext{
${ }^{5}$ From the poststructuralists' point of view the text is gaining meaning in the relationship to other texts, and meaning of the text is distributed in this network of interrelated texts. Intertextuality of the text comes in part from the associations, which texts form between themselves, using the relationships between them, and partly from the associations combining the texts with the context in which these texts are perceived (Tredinnick, 2007,180).

${ }^{6}$ Fields of the 6XX group.
} 
(Transactional/Reader Response Theory) (Rosenblatt, 1978). Accepting the assumptions of the theory of schemata, stating that each individual is unique due to the construction of her/ his mental schemata, especially in relation to the areas of personal experience, the author points out that also every reading experience is unique for each person. The basic assumption of Rosenblatt's theory is the individualization of every reader's reading experience because of the uniqueness of his/her mental schemata which form the basis for this experience.

Another important feature of this theory is the ability to distinguish between two types of responses to texts being read. They are called analytical (efferent) and synthetic (aesthetic) responses. The former are useful for gathering information about facts; the latter are more personal and emotional. Both types in their pure forms are the opposite extremes. A complete dichotomy, that is, "pure" responses of each kind, is rarely present, usually it comprises of both analytical (informational) as well as synthetic (emotional) elements. The type and level of response specify the nature of a transaction which occurs during reading, treated as a unique situation of the text and the reader encounter, and the purpose with which the reader enters this relationship. The reader accomplishes a transaction with the text constructing its narrative world, and the narrative world closes the transaction by reconstructing the mental schemata of the reader. It is a continuous process in which the reader creates and modifies the situational model throughout the duration of the textual experience (Rosenblatt, 1994, 1063).

In this model, it is important to distinguish the concept of transaction from the concept of interaction. According to Rosenblatt, interaction usually means the operation performed by separate individuals where one influences the other, whereas the transaction designates bilateral relationship, in which one element shapes and is shaped by another in mutually constitutive situations (Rosenblatt, 1988, 2). Human activities and relationships are considered as transactions in which individuals are combined with social, cultural and natural elements. The concept of a transaction has significant implications for the study of language activity, in particular for writing and reading, which always areinformation activities, too. The use of genre conventions enables authors, readers and texts to meet all together in the space of transaction. Language is always internalized by the individual during a transaction with a specific environment. The act of using the language is neither fully public nor private. It is performed by the individuals but it also contains public elements. Enunciating each word one realizes that it does not function in isolation, but always in some verbal, personal and social contexts. This knowledge is individual because it is acquired in the course of personal experience ${ }^{7}$, but all processes of human cognition and communication are so focused on other people that the conventions of communication are created almost naturally. As stated by Michael Tomasello, a person uses acts of communication to encourage others to accept his/her way of thinking. He/she cooperates in the communication processes in order to facilitate the reception of his/her perspective by others, and simultaneously he/she is also constantly forced to take the perspective of others. Conceptualization conducted from many different perspectives is such a natural feature of human cognition that it is hard to imagine a different course of action. The individual

7 This experience is collected in the mental schemata in the form of the transactions, both linguistic and non-linguistic, fulfilled between the individual and the environment. It consists of objects and events of the surrounding world and people experiencing it. 
must think (simulate, visualize, draw conclusions) what his/her communication partner thinks about his/her thinking. Such adjustment requires self-control and assessment of communication acts in terms of their intelligibility from the perspective of partners in communication, each with his/her own individual knowledge and motives, and the shared context with the sender (Tomasello, 2015, 133).

Writing and reading should not be treated as fully dichotomous processes. Both linguistic activities are similar, but also different. Reading and writing are based on the construction of meaning performed in conjunction with mediated texts and cultural-historical context (Smagorinsky, 2001, 137). During the transaction both the author and the reader use schemata created during their experience on the basis of which the process of creating meanings is organized. However, the context or situations in which both operations are carried out, differ much. Every act of reading is an event, a transaction, which involves a specified reader and a particular configuration of characters on the page, done at a set time and context. The complex, non-linear, self-corrected transaction is performed between the reader and the text stimulating and meeting (or failing) expectations, supporting the construction of widened, often modified "meaning". The meaning neither resides ready-made in the text nor in the reader, but it is formed during the transaction between them both. By creating the meaning the reader composes his/her "own" text in the transactional space. According to Smagorinsky, one should rather use the plural, that is, speak about readers and texts, because neither the text nor the reader does execute this transaction alone; it is done in the dialogue with the predecessors whose recurrent transactional practices led to the creation and modification of genres. The text is placed among the mediation tools, through which its meaning could potentially be substantiated: genres, social transactions with other readers, cultural schemata (Smagorinsky, 2001, 141).

Similar to the reader, also the author always performs transactions with the personal, social and cultural environment. These transactions are made with a constructed text too (Rosenblatt, 1988, 7). It means that the process of writing must be seen as always containing personal, individual as well as social and cultural elements. Writing is always an event in time, occurring at a specific moment in the life of the author, under specified conditions, under the influence of specified external and internal factors, performed for a specified purpose. Its repeatability leads to the conventionalization of text content and format.

However, unlike the reader, for whom the text must always be available, the author starting his/her work on a blank sheet of paper or in front of a blank screen, has access only to his/her own mental structures, previously constructed, including knowledge of genres. This earlier linguistic experience, gained in everyday situations, provides the material of which the text is constructed. As in the case of the reader, any new meanings arise from restructuring or developing the set of experiences with which the author performs his/her task.

Rosenblatt says that writing can also be considered as reading, even twice. Firstly, the author is the first reader of the text. Such reading must naturally be regarded as an integral part of the creation process. Secondly, writing is considered as part of the potential transactions with other readers. During this kind of reading the author detaches himself/herself from the text and reads it from the point of view of the potential reader, which means that he/she is trying to assess the meanings which will be assigned to the text by the recipient. The resulting text must be read as a source of meaning, but also as ways of achieving the objectives of the recipient taken into consideration (Rosenblatt, 1988,10). Thus, the author 
constructs the potential reader, with his/her objectives, needs and perceptual possibilities. Both sides of the communication process always take into account the purpose and context of the other party of the process. This way mental constructions are raised, like "I think, he thinks, that I think" (i.e. social recursive inference) (Tomasello, 2015, 127).

As one can see, reading and writing transactions are simultaneously highly individual and strongly social actions, just like all processes of information/knowledge. The nature of knowledge relationships are transactional, since the possession of knowledge implies the existence of a person who knows and vice versa (Rosenblatt, 1993, 380).

\section{The implementation of the aforementioned theories in the information organization}

Both to the librarian and the library user, and even to people who has never used the library, it is clear that it is the institution where actions on the texts are carried out. At the same time we all probably have in mind the texts of documents which are added to the library collection in various ways (purchase, exchange, gift, etc.) and are subject to the processes of information organization performed by librarians (information organizers). Increasingly, we think about libraries as the storage place for the documents of various types, not just textual ones. In this case, the document can be interpreted much more broadly, approaching docuverse, which is the universe of documents (Gnoli \& Ridi, 2014, 448). In this sense, according to the definition ("controversial" as the cited authors state), everything may potentially be a document that is the source of information in the material form, possible to be used as a reference in the study, or as a pattern. If any physical object in the universe can - in some circumstances, from somepoint of view and for some purposes - be used as a source of information, the entire universe can be treated as a great collection of documents. Then the universe is, in a sense, equated with docuverse. The exemplification of the essence of both the universe and all its parts is a document, material thing, which contains information structured in a specific way (Gnoli \& Ridi, 2014, 456).

Such understanding of the document has been used as a basis to establish the concept of GLAM institutions (galleries, libraries, archives, museums). Institutions of this kind collect documents, regardless of form, purpose and origin (the broadest context of cultural heritage) and circulate these resources to all or any interested persons, with the fullest use of information technology. They cooperate at all levels: local (e.g. library, archive, museum belonging to one university), over-institutional (common interests and tasks) and global (shared values). This way also standards for the information organization are developed, such as metainformation standards, the unification of which is one of the conditions for cooperation. Despite the often parallel development of different standards in each type of the GLAM institutions, these communities frequently experiment with other solutions. As a result, a rich set of textual tools is created, used for the practice of resource representation, individually adapted to a particular genre of documents (Elings \& Waibel, 2007), which forms the basis for different user transactions.

More rarely we consider libraries and all kinds of information centers or GLAM institutions, where information is organized, as the places where transactions of texts creation by the information organizers and their reading by anyone interested in access to information 
contained in docuverse are performed. The creators of these texts, that is the cataloguers, usually do not think of themselves as authors and do not perceive their operations as creative writing, much less any special writer's achievement (Feinberg, 2015, 45). We can distinguish numerous genre groups created and used in the library information organization:

(1) genres of publications, collected from outside of the information system;

(2) genres of texts used for the information organization: the vocabulary genres and genres of instructions and standards;

(3) genres of texts created as a result of the transactions of the information organization: bibliographic/catalogue descriptions;

(4) genres of users' information requests;

(5) genres created by the designers of information systems, the most interesting among them being the user interfaces.

Among numerous genres of texts created in the libraries, the most characteristic for this activity are text documents, which usually are lists, such as catalogs or bibliographies, used to describe and circulate other documents, aimed at the organization of information contained therein (the third group of genres). These descriptions are generally called metadata (metainformation). They are used for the information arrangement (organization) contained in the texts of the first group of genres. The organization of this information represents a particular form of social action (Andersen, 2015a, 17), which is a transaction. The text of bibliographic description, resulting in the processes of information organization, serves to mediate between the text of the document of the first genre group and the transaction of searching the text through the library catalog, using texts genres of the fourth group. This mediation is characterized by multiplewriting/reading transactions.

Such an understanding of the person-document library transactions is consistent with the more general understanding of the person-object transactions presented by Mihály Csikszentmihalyi, who claimed that in order to understand who people are and whom they can become it is necessary to understand what is happening between people and things they use (Csikszentmichalyi \& Rochberg-Halton, 1981, 1). Only personal commitment, a relationship with the artifact enables it owner to acquire meaning and experience. Transactions of the person-object type are mental activities, not just physical behavior. The result of the transaction depends on the intention, direction or purpose, which is the main feature of the action significance. The process of assigning meaning is the transactional communicative act, wherein the objects performing the role of a sign are used. The communication process including this type of objects, allowing exploration of the meaning of the sign, provides a person with some access to this meaning and, as a result, the development of his/her knowledge.

Access to the resources collected by the GLAM institutions is done through various transactions and the texts of different genres supporting them, collectively recognized as the activities of the information organization. At the same time the organization of information also co-creates a system of differentiated genres and transactions through the coordination of human and texts activities in the context of the information organization. It is worth remembering that the information (content) always functions in a specific form, and these forms are adapted to people's activities aimed at production, storage and use of the information contained in the texts (Bazerman, 2012, 378). As already mentioned, these three attributes of the text characterize the genre. Information is internalized in the form 
specified by the genre and forms further social transactions. Without the knowledge of the forms of information and its functions in the communication activities of the community the possibility to locate and explore the meaning of information is limited.

The genre, as an element of the transaction between the reader and the text, helps to identify ways of organizing people, activities and knowledge by means of textual information. Each transaction between the text and the reader has some specific goals. This means that mediated information, codified and organized with texts shapes the goals and further actions supported by the text. The genre or the genre system builds a transaction affecting the structures of knowledge. The genre is a manifestation of specific information organization. The knowledge about text genres helps to create new knowledge structures according to the type of transaction, with genre as one of it parts. In this manner, processes of information organization become understandable, since ways to support the information organization based on the typical action and recurrent transactions of which genres are one of the parts, become clearly visible.

The information organization is arranged in specific, recurrent and typical transactions of people and texts and the information contained therein. This means that studying the information organization requires one to achieve some understanding of specific situations and social activities within which activities of organizing information are placed. The subjects of the study are repeatable patterns of communication activities performed by people and organizations in recurrent situations. People (users of information) in transactions with texts form meanings appropriate to formulate and execute social activities through which they accomplish their goals. Genres of these texts are the tools used to achieve these objectives.

Jack Andersen writes that the information organization can be understood in two ways (Andersen, 2015a, 34). Firstly, it can be seen as a result of the transaction between the information user and the text containing information. The information organization is subject/purpose of the transaction. Then one takes the point of view of the information organization system designer, who is the subject. The tools are texts, ideas, users, and other forms of information organization. The designer of information organization forms cannot ignore tools used in other transactions and by other users. He/she must be sensitive to the genres implemented by the users in their discursive actions and adapt to them, in order to make the correct design of forms of information organization. The activities of the designer are mediated by organized information artifacts and other transactions.

Secondly, information organization tools can be considered as tools for the implementation of other transactions. This means the information organization tools are treated as the tools for mediation. The forms of information organization are used by people with other tools in the course of the transaction. This approach is common for people involved in transactions, whose primary purpose is to create texts containing information, where information organization is used as one of many tools. Despite this, however, users of information organization forms are not only its passive users, but also its creators, as they create ideas, beliefs, meanings, values and information, organized by the information organization. The information organization not only represents the domain, but also through the genres and transactions constructs the domain in multiple ways.

From a text user perspective which was taken by poststructuralists, who were dealing with the theory of the text (Tredinnick, 2007), it can be interesting to discuss Genette's concept of so-called "paratext", which provides resources, tools with which the text becomes 
the document and is offered for transactions to its readers and, more generally - to the public (Genette, 1997, 1). The transactions are used to implement some kind of a strategy of the text impact on the receiver - it, at least partially, directs interpretation ${ }^{8}$ and impose on the meaning (Tredinnick, 2007, 177), which facilitates communication from the sender point of view. Due to the placement of paratext elements they are divided into those which are placed together with the text in one volume (e.g. title, introduction, comments) and which are named "peritext" and elements spatially separated from the text (e.g. interviews with the author, reviews, letters) called "epitext". It is therefore considered that the bibliographic description is usually a kind of the epitext ${ }^{9}$. Its function, as in the case of each paratext, results from the fact that it is completely secondary discourse, designed to handle transactions with the text.

\section{Transactions with the text of the library catalogue}

In libraries and other information centers multi-level transactions of the person-document type occur, with the proviso that the document must be interpreted much more broadly than in the traditional librarianship. These transactions are performed between persons living and fulfilling vital functions, including cognitive ones: they have experience, memories, knowledge, emotions, character traits, their own environment and - the documents constituting the complex representations of some part of the reality. The transaction takes place during the meeting of both elements, when the creation of a unique experience happens that can arise only between that individual in that moment, in that place (cf. generic chronotopies $^{10}$ ), and that object (document) (Latham, 2014, 551). In this part of the paper the author focuses on the transactions occurring between users and text documents the content of which is metainformation used for specific social actions (information organization).

Transactions in libraries are implemented at various levels, including many meanings. The library is an information system where knowledge transactions are performed, involving information in mainly textual form, so thetransactions in question are those of writing/reading. They concern documents both in the broadest sense of docuverse andthe traditional sense of textual, material sources of information. These documents function within genres, understood as typed symbolic actionstaken in response to the recurrent transactions in which they are used. During the recurrent transactions, where documents are used, people construct their genres. At the same time text genres of documents in use help people to construct recurrent transactions. In the case of an information system such transactions occur between people generally pursuing two different social roles (having needs being result of the information gap - seeking documents, and creating the

${ }^{8}$ Function to direct interpretation is done by highlighting particular associations of the described work with other works and by isolating particular "qualities of significance", such as author, title, publisher and date of publication.

9 The bibliographic description of the text can be also treated as a peritext, e.g. in the situation of CIP (Cataloguing in publication), where the description is printed with the text or in situation of so-called embedded metadata.

${ }^{10}$ Chronotopies are the categories of time and space, assembled in a one, carefully constructed unit used to distinguish genres. 
documents and/or helping to access them) and such documents as a computer system or the library building, OPAC or another catalogue, including the card catalogue, the catalogue description (record), the publication, the librarian ${ }^{11}$. Filling the information gap can cause the need to search for information, which takes place through transactions carried out using the sensemaking strategy, which lead to the making of meaning of the concept, area of expertise, situation, problem or task (Zhang \& Soergel, 2014, 1734). Sensemaking is a sequence of actions aimed at defining and closing the information (knowledge) gap (Dervin, 1998, 37), which is the acquisition of knowledge.

According to Rosenblatt, people create meaning, make sense of new situations or transactions by using, reorganizing, adjusting or expanding elements collected and selected from a personal linguistic-experiential reservoir, which is the result of previous transactions, linguistic or any other (Rosenblatt, 1993, 381). In these activities the acquired experience (e.g. during previous searches) is applied, as well as already possessed knowledge (e.g. search results), social and psychological hypotheses, expectations for language and publication (genres); they are the basis both for the construction of meaning and the discovery of the author's intentions (Rosenblatt, 1988, 7). The meaning grows with the internalization of further information (development of retrieval transactions). Not all strategies and the resulting actions, motivations and needs of the individual must be reasonable and lead to a successful transaction with an information system (Godbold, 2006), which involves the selective attention, making "selection of activities". During the transaction we focus our attention, consciously or unconsciously ${ }^{12}$, on specific aspects, parts of the text. Attention may be directed to the wider or narrower area of issues. It can be controlled or chaotic, intense or superficial (Rosenblatt 1988, 4). When searching, the user can pay attention to the elements of the description he/she considers as searchable, and when identifying a document - to the whole description. According to Wilson, the failure of the transaction completes the process of collecting information, the success leads to its use, allowing full or partial satisfaction of the conscious need (the gap), or if no satisfaction is reached, the user is allowed to repeat the search transaction (Wilson, 1999, 251). The use of information may result in further transactions.

Let us investigate library transactions and their evolution on the example of transactions with the text of bibliographic description (record). These transactions were evolved due to the development of librarians' awareness and the use of subsequent information technologies. On the continuum analytical (efferent) - synthetic (aesthetic) transactions they are situated far closer to the first extreme. Even as for typically efferent transactions, extremely strongly regulated text genres are in use, and this has an impact on the transactions because these regulations are their part. Since the 19th century there has been constant progress in the standardization of all aspects of creating and using the text of bibliographic descriptions and their genres in libraries; this process has deepened and accelerated due to the application of information technology.

11 As you can see, the librarian (information organizer) appears here in a dual role: as the person performing transactions with documents and as a source of information (document) from which the user executes transactions.

12 The role of the consciousness in reading is increasingly being included in the study. According to Stanislas Dehaene, reading involves many series of unconscious actions; the whole process of visual word recognition takes place automatically, without any involvement of the consciousness (Dehaene, 2009, 92). 
The first significant reflection on the transaction between the user and the catalogue, and specifically the bibliographic description, resulting with the standardization effort, appeared about mid-19th century in the Great Britain and the United States. Antonio Panizzi, the director of the British Library presented 91 rules on the catalogue organization, considered the first major principles of cataloguing. These rules concerned the conditions of the user's selective attention. Panizzi believed that the reader should know identification data of the work which he/she needs, while we did not expect him/her to know all the details of its individual editions. Panizzi assumed that the reader had a right to expect that catalogues would provide him/her with this type of information (Vellucci, 1998, 105).

For Panizzi the construction of the catalogue was more than a physical record of the data about books. He noted the importance of the distinction between the search with the use of specific intellectual units - works and possibilities offered by the usual inventory (the register) of books. The identification function and the ordered creation of the works and their varying manifestations have become fundamental and very pragmatic guidance to the organization of information in the catalogue, specifying the possible transactions.

Panizzi ideas about the catalogue transactions can be summarized in several points:

- the user who knows the name of the author (knowledge) can find (transaction) metainformation about all his works;

- the user can distinguish (transaction) between different expressions (e.g. translations) and manifestations (e.g. editions) of given work (knowledge);

- the user should not only find (transaction) the needed publication (knowledge), but also get information (transaction) about all editions of a work represented by the publication and related works.

In other words, the catalogue that is only a list of items held in a library cannot be considered to be useful in library transactions. The user uses the catalog to study the intellectual content of the works. In order to be useful in transactions, the catalog must clearly identify the work, assist the user in making choices, including the presentation of the relationship between the works, their expressions and manifestations. These relationships form the meanings discovered by the user in subsequent transactions.

Similarly, some years after Panizzi, Charles Cutter described the user-catalogue transactions in the following way (he referred mainly to so-called local dictionary catalogues):

- simple transactions: opportunity to find books the author, title or subject of which is known, which means directing his/her attention to those elements of the description. The transactions were possible to change in time, e.g. after introducing the title entries for anonymous books, next step was to make title-entries for all books, which have any good word in the title to refer them;

- complex transactions: opportunity to explore library resources by means of the author's name in question, witha given subject or with a particular type of literature;

- assisting the user in the transaction of books selection: following their editorial (bibliographic) data or their nature (the literary genre or theme) (Smiraglia, 2002, 334). 
Despite the fact that the transactions as described above ${ }^{13}$ are the foundation for the modern catalogues and bibliographic records, as well as they direct thinking about the transactions of users described in FRBR (Dimec et al., 2005, 214), the feasibility of transactions in the manual information systems (e.g. card catalogues) was very limited, at least in comparison with further opportunities arising with the development of information technology. Consider the role of the heading in the catalogue record. In the library transactions it played a dual role: it determined the catalogue order, and at the same time metainformation search capabilities (power). One of very important elements of the transaction was the catalogue order, always single type ${ }^{14}$, completely determining the possibilities of access to the text of the bibliographic description. The order in relation to the catalogue text serves as a paratext - sort of a table of contents or an index. Both the order and the catalogue description genre were regulated already in the card catalogue with the standards mentioned earlier.

The genre of the catalogue description is characterized by a specific, standard text structure, which determines possible transactions. One of them is unambiguous identification of the text genre group 1 (primary texts) described with the text genre group 3, which enables their retrieval. The type of the transaction is also conditioned by the form of the description text; for example, the manual information systems always awarded the conciseness and space savings. The entire text of the bibliographic record should have fitted one card. It was achieved with restrictions imposed on the authors of description texts, such as "the rule of three" (limiting the amount of responsible persons to maximum three personal names per card) and use of standard abbreviations. That was the reason for limiting the possible transactions, for example, the search by names of subsequent authors (except the first one), if there were more than three authors, was impossible. If there were two or three authors, there was no possibility of direct search by the name of the second or third author (the need for the use of reference cards). Also Cutter's proposal for search by the work title was not implemented or implemented only indirectly. Only books by more than three authors were described under the title header and the uniform title was in use as well. It meant the user was unable to search by titles in the vast majority of cases.

In the case of the computer catalogues, their capabilities in this regard were considerably increased by combining several components of the index (e.g. several names) of several orders (e.g. several types of names plus subject headings) in one retrieval expression. Also some information, rarely searched in the manual system because of the practical reasons, like publishers or languages, became transactional. At the same time it was necessary to move lists of access points to separate texts of authority files; the texts of bibliographic and authority records were linked with close relations. Still, the text genre of authority files had to respond to the needs of transactions for which it was designed, for example they included information used to identify transactional element in a unique way, for instancea

${ }^{13}$ In addition to the works of Panizzi and Cutter in this area one can mention such works as Prussian Instructions (1908), ALA Cataloguing Rules for Author and Title Entries (1908 and 1949), The Paris Principles (1961), the Anglo-American Cataloguing Rules (1967) and International Standard Bibliographic Description (since 1974).

14 There are two basic catalogue order types: alphabetic and systematic, which are rarely mixed, although there are attempts to connect them, e.g. with use of indexes. The dictionary catalogue, mixing author and subject entries in one alphabetical order, allows for simultaneous transactions of different types. 
person, without giving extensive "encyclopaedic" information, if it was not necessary for the identification. Surprisingly, the OPACs still witnesssome restrictions for transactions, resulting from the previously used manual technology, such as the aforementioned "rule of three" that has no justification in computer systems.

The flagship standard at this stage of transaction construction was and still is (though constantly modified) the MARC format, including both genres of catalog descriptions and authority records. Among others, in order to maintain "the rule of three", headings (entries) in MARC bibliographic records are placed in several parts of the record ${ }^{15}$, mostly fields 1XX (the main entry) and 70X-75X (the added entry) and, for headings of another type, fields $6 \mathrm{XX}$ (subject access) and $80 \mathrm{X}-83 \mathrm{X}$ (the series added entry). For a long time they were the only access points to a record text, indicating the nature of the initial knowledge required from the catalogue user ${ }^{16}$. Modifications of the MARC format have often been used to extend the possible types of transactions, an example of which can be 1993 implementation of 856 field (electronic location and address), which enabled transactions associated with remote access to the described electronic resource.

In addition, if texts of all genre groups applied in information organization, particularly texts of the genre group 3 - the paratext (the bibliographic description) and texts of the genre group 1 - the described document text, are available in electronic form and remote access (i. e. cybergenres) ${ }^{17}$, it is possible to combine transactions with all these texts in a way convenient for the user; digital libraries operate in this mode. In these and similar places the non-MARC genre of description texts, but of the same genre group is usually used, for example, some based on the Dublin Core metainformation standard.

Recent improvements in the capabilities of the transaction are reflected by the enhancement of access to both bibliographic records (text of the genre group 3), as well as authority files (text of the genre group 2). The first concern the use of full-text retrieval transactions, the latter transfer the texts of genres of all groups used in the information organization into cloud-based Linked Data. This work involves the use of numerous new standards such as XML/RDF, OWL, OAI-PMH, URI, FRBR, RDA and others.

These changes in information technologies, resulting in new types of user transactions with texts of descriptions, would be difficult to implement without previous changes in the approach to the idea of a catalogue from a closed silo of content to a set of units (the entities) of text of a description in an appropriate manner representing meaning, realization and the physicality of information resource (Baker et al., 2014, 562). The basis of this work is the FRBR model with its four core entities (Work, Expression, Manifestation,

15 Restrictions on the creation of a main header of the bibliographic record for the first author (the field 100 ) only in the case of no more than three authors (name of others were placed in the fields 700) should be considered as a residue of principles used in the card catalogues; for more than three authors, the name of the first one (and only this!) was entered in the field 700. Such a procedure could be explained only by need to print the catalog card from a library system. These rules have changed only after adapting them to the RDA, a standard which introduced new types of transactions.

${ }^{16}$ It is necessary to mention that what is possible to find in an OPAC depends not only on its data structure but also on the library system (software) possibilities offered by its manufacturer.

17 We can notice that making the catalogue accessible on the Internet as OPAC means that the status of the text is changed from the non-published manuscript to the published document. It is published usually as Open Access, and almost always without the authorship attribution. 
and Item), along with related models: FRAD for authority records and FRSAD for subject authority data. This model was used for the creation of RDA, the successor of AACR and ISBD. The model of RDA is based on FRBR entities, in the sense that it allows the users to create texts describing these entities, mainly the four mentioned. Parallel to RDA, the Library of Congress developed the BIBFRAME model, also based on FRBR, as the successor of the MARC format: an abstract Work entity is concretized there as an Instance entity. The emerging of the Semantic Web idea and then the Linked Data cloud led to the publication of these models as vocabularies expressed in RDF and OWL standards. FRBR and RDA have been translated into RDF and BIBFRAME has originally been designed and implemented in RDF format. Information managed with the help of these models may be presented as expressions in the RDF syntax. These changes gave rise to new genres of bibliographic texts. Their "meaning" is suitable for automated processing and thereby enabled the implementation of a new type of transactions of reading of these texts, with the use of the network of relationships between the entities and their values.

The user's feasible transactions with the text of a bibliographic description in the OPAC for a long time have been artificially restricted in such a way that they were possibly similar to the transactions with a card catalog description. One of the limitations was to narrow the search capabilities to only a few predetermined elements of the structure of the record. For example, for many decades the already mentioned "rule of three" was employed, although it lost its rational justification since the beginning of the computerization of information organization. It was necessary to wait long for the observation that the text of the bibliographic description, as any text in electronic form, can be full-text searched, and authority files rather serve to harmonize the forms of the text of description genre than to organize the search. Systems capable of such transactions (the so-called discovery systems) were created to make OPAC retrieval transactions similar to those used in search engines, including the use of indexes created in the course of full-text indexing (Breeding, 2015 , 24). Consequently, the search transaction can be performed now with each element of the text (character string), not only those managed with authority files. At the same time, making an effort to simplify the transactions executed, the users lose the ability to distinguish text elements that may be present in different senses (e.g. a personal name as the subject and the object of the work). Also the end-user access to another genre of texts, which we have discussed here, that is the authority files, is limited in many integrated library systems (ILS).

This restriction will probably be removed by the use of another innovation associated with sharing of paratexts, namely their shift to so-called cloud of data. It is directly related to the usage of Linked Data technologies in information activities. It concerns the text genres called vocabularies (ontologies), which in the case of Linked Data are interpreted very broadly. This name covers both vocabularies used at the level of pragmatics, containing the values of metainformation elements, also called controlled vocabularies (authority files, subject vocabularies, code lists of languages, geographical names, etc.), as well as the sets of terms used on the semantic level, previously known as formats or metainformation schemas (text genres including lists of metainformation elements, fields and subfields in metainformation formats), which are lists of predicates of the RDF triples. One deals here with text genres containing classes of objects, object names and bibliographic relationships that can connect the former. With the use of texts of these genres (belonging to the 
group 2), including all the elements necessary for the construction of texts used in library transactions, texts belonging to another genre group - the bibliographic description - are created. Thus the cloud of data contains metainformation vocabularies of both levels: semantic and pragmatic, encoded using the markup languages (e.g. RDF) and thus available for immediate computer processing. Identified elements of the text (for bibliographic description: works, people, institutions, places, content elements, etc.) are described with languages such as RDF and OWL and placed in vocabularies, where their meaning is defined by a description of their relationship with other elements. Transactions of creating texts of document descriptions can be implemented through cooperation among libraries, libraries with other institutions and individual users.

This distributed data model allows "anyone to say anything about anything": we should also add - in every way (which means creating new genre conventions). The situation must lead to the diversity of opinions and disagreement over the meaning of the elements (Allemnag \& Hendler, 2008, 7). It resembles more Wikipedia than the library catalog circumstances. On the other hand, dense network of connections (links) to complementary data created by a reliable creator (e.g. the library) increases the value of data beyond what can be offered by a simple sum of the resources treated individually (without connections). This type of text presence and use makes fundamental changes in the transactions of their users, as a transaction can change its type, from the reader-text transaction to the (co-) author-text transaction.

Transactions of creating texts of bibliographic descriptions also include their placement in the cloud by their authors. As demonstrated above, all elements necessary to create these texts can be collected from the vocabulary text genres of Linked Data together with their meaning. The transaction between the text of bibliographic description and its author resembles a building made with Lego bricks; from texts belonging to different groups of genres, elements are taken to be inserted into a text of another genre. These elements may be different for different cultures, causing the diversity of the transactions. The transactions in question were always performed in a similar way, except that the elements of the description text were taken from the paratext genre directly associated with the text (e.g. for the book it was mainly the title page), earlier having beentransferred to the collection of paratexts (the library catalog) physically separate from the text, and now collected as a link to the vast resources of the global data cloud, where the text and the paratext operate together. In addition RDF is designed to merge data from different sources in a constantly changing universe, in which currently available information can be fragmentary or incomplete.

It is not the sole difference. At the same time the scope of the text, with which transactions could be performed, is expanding. One of most important features of the docuverse is its extensibility from "Giant Global Graph" or "Global Data Space" at the most general level to NanoPublication at the most detailed level (Gradman, 2014, 251). In this way the differences between always different text genres now disappear (this applies primarily to scientific publications), while there is an increase in the number and the types of possible transactions that resemble navigation in a global network. More specifically, one can notice the disappearance of differences between the texts of documents containing the information, the data sets being the basis of these documents and metainformation describing them. The electronic text and its cybergenres become much more dynamic, allowing creation of richly contextualized information aggregations collected on the Web, which also offer 
the possibility of new transactions, such as automated reasoning or construction of new genres as visualizations of research data aggregates. On the other hand, the text reduced to groups of words ceases to express the author's intentionality, becoming susceptible to the creation of new intentionality, of new authors. However, with this intentionality they are still understandable to humans (Thellefsen et al., 2015, 517).

The bibliographic record, as a text of the genre group 3 is somewhere in-between of both extreme ends on nano-universe continuum of texts. It is composed with a set of NanoPublications aggregated into one, meaningful whole. The meaning results from the aggregation order and from meaningful relations between elements making metainformation. The elements are collected from the texts genre group 2, placed in the Linked Data cloud. Such an arrangement of the information organization environment is a basis for new methods of creating and implementing library transactions.

Global structures in question include not only the library resources. It is rather that the text resources created in the libraries are becoming a part of a global transactional space, formed in a distributed manner by the Web users. Anyone who has something to say may submit his/her information. One result is a greatly expanded range of available information. For example, each person is presented on the Web in a much more multifaceted manner than before, not only from the point of view of published works, as it is in the OPAC and related authority files. Any data may be attached to the personal ID, for example concerning the person's family, jobs, hobbies, status of ownership (real estate, vehicles), skills (driving license, courses) and any other such as the information about life events with relationship to those who are complicit in these events. These trends are reflected in the solutions adopted in RDA, where alongside the traditional elements used for personal identification, including personal name, dates related to the person ortitles, new elements are applied, such as profession or occupation, area of activity, related groups and individual identifier. Enhanced elements include language of the individual, gender, address, country, place of residence, place of birth and death (Moulaison et al., 2014, 34), resulting in the formation of a new $37 \mathrm{X}$ group of fields in the MARC authority record. These data inevitably become the part of authority files, understood as a complete resource of biographical data on the author (Roszkowski, 2015), as the library metainformation becomes part of the global graph. All these text cybergenres, combined with numerous relationships form the basis for the transactions possible to perform.

The diversity of the points of view, supported by the afore-mentioned Semantic Web standards, can help support various transactions. Currently metainformation interoperability, understood as agreed upon knowledge of genres, is no longer subject to compliance with a rigid set of meaning restrictions, which were characterized by the arrangements to be applied from the Paris Principles, by AACR and MARC, until ISBD emerged. As RDF is designed to merge data from different sources the reasonable level of consistent overlapping of meanings is sufficient.

\section{Conclusions}

In-depth application of the theories presented in this article, with the leading theory of the transactions, in the area of information organization can help describe and understand the 
changes made here, largely resulting from the development of information technology.As a result of these technologies the nature of text documents that are the basis for the information organization is changing, new genres are developed. New genres (e.g. cybergenres) are the result of the construction of new communication situations, while affecting their understanding at the same time.

Efferent transactions related to the information organization and the text genres used in the processes are regulated by huge number of standards, some of which were mentioned in the article. Many of the transactions in question resemble metatransactions, used for the internalization of information to obtain the knowledge necessary to perform further transactions with the subsequent texts. From this point of view, each metatransaction with paratext, performed successfully, enables the implementation of further transactions with the texts. The success of such communication depends on the ability of the reader to reconstruct the intentionality of the author (information organizer), and to determine communicated meanings and its contexts. As a result of the transactions for the externalization/internalization of information, knowledge structures of participating individuals are modified (Thellefsen et al., 2015, 515).

Important elements of these transactions are text genres, as conventions constructed in recurrent transactions. These conventions are socially agreed upon on the basis of shared experience gathered by the author of utterance and its interpreter (receiver). The nature of the transactions is gradually modified by achieving consecutive agreements between both actors and blurring the boundaries between them. The joint appeal to the conventions makes possible the meeting of the text and the reader in the transactional space. The construction of transactional space (and thus the discovery of meaning) may, however, be quite different for individuals with different experience, despite the use of the same genre conventions. The standardization, leading to genre regulation, used in information organization is focused on limiting these discrepancies. It forms the part of the culture where the creation and reading of texts serving the information organization takes place, suggesting thus better and worse methods of meaning construction.

Information organizers and information users are engaged in culturally mediated processes, in transactions with the historically shaped resources of texts, contexts, intertexts and intercontexts. Bibliographic relations are textual tools serving the creation of structures in the bibliographic text genre, which can be considered as bibliographic intertextuality. This points to the interpretive role of bibliographic relationships; the meaning of bibliographic description stems from its relationship with other descriptions and other texts. Despite the fact that these transactions are related to individual knowledge, they act in relation to community of users and texts they read. As a result, texts (also bibliographic record texts) reading affects the social position of individuals who can properly acquire knowledge during the writing/reading transactions. Thus in the space of library transactions meanings are constructed in the processes and practices that involve writers and readers of bibliographic descriptions.

\section{References}

Allemang, D.; Hendler, J. (2008). Semantic Web for working ontologist: effective modeling in RDFS and OWL. Amsterdam: Morgan Kaufmann. 
Andersen, J. (2015a). Re-describing knowledge organization - a genre and activity-based view. In: J. Andersen (ed.) Genre theory in information studies. Bingley: Emerald Group Publ., 13-42.

Andersen, J. (2015b). What genre theory does. In: J. Andersen (ed.) Genre theory in information studies. Bingley: Emerald Group Publ., 1-12.

Auken, S. (2015). Utterance and function in genre studies: a literary perspective. In: J. Andersen (ed.). Genre theory in information studies. Bingley: Emerald Group Publ., 155-178.

Baker, T.; Coyle, K.; Petiya, S. (2014). Multi-entity models of resource description in the Semantic Web: a comparison of FRBR, RDA and BIBFRAME. Library Hi Tech, 32(4), 562-582.

Bakhtin, M. (1986). Estetyka twórczości słownej. Warszawa: Państw. Inst. Wydawniczy.

Bazerman, Ch. (1994). Systems of genres and the enactment of social intentions. In: A. Freedman, P. Medway (eds.). Genre and the new rhetoric. London: Taylor \& Francis, 79-101.

Bazerman, Ch. (2012). The orders of documents, the orders of activity and the orders of information. Archival Science, 12(4), 377-388.

Bhatia, V. (1997). Genre analysis today. Revue belge de philologie et d'historie, 75(3), 629-652.

Breeding, M. (2015). The future of library resource discovery. Information Standards Quarterly, 27(1), 24-30.

Capurro, R.; Hjørland, B. (2003). The concept of information. ARIST, 37(1), 343-411.

Chanal, V. (2012). Building knowledge for innovation management. The experience of the Umanlab research team. VINE: The Journal of Information and Knowledge Management Systems, 42(3/4), 396-415.

Csikszentmihalyi, M.; Rochberg-Halton, M. (1981). The mining of things. Boston: Cambridge Univ. Press.

Dehaene, S. (2009). Reading in the brain. The science and evolution of a human invention. New York: Penguin Viking.

Dervin, B. (1998). Sense-making theory and practice: an overview of user interests in knowledge seeking and use. Journal of Knowledge Management, 2(2), 36-46.

Devitt, A. (1991). Intertextuality in tax accounting. Generic, referential, and functional. In: C. Bazerman, J. Paradis (eds.). Textual dynamics of the proffesions. Historical and contemporary studies of writing in professional communities. Madison: Univ. of Wisconsin Press, 336-380.

Devitt, A. (1993). Generalizing about genre: new conceptions of an old concept. College Composition and Communication, 44(4), 573-586.

Dijk, T. van (2014). Discourse and knowledge. A sociocognitive approach. Cambridge: Cambridge University Press.

Dimec, Z.; Žumer, M.; Riesthuis, G. (2005). Slovenian cataloguing practice and Functional Requirements for Bibliographic Records: a comparative analysis. Cataloging \& Classification Quarterly, 39(3/4), 207-227.

Elings, M.; Waibel, G. (2007). Metadata for all: descriptive standards and metadata sharing across libraries, archives and museums. First Monday [online], 12(3), [21.10.2015], http://firstmonday. org/issues/issue12_3/elings/index.html.

Feinberg, M. (2015). Genres without writers: information systems and distributed authorship. In J. Andersen (ed.). Genre theory in information studies. Bingley: Emerald Group Publ., 43-66.

Gajda, S. (2009). Gatunki wypowiedzi i genologia. In: Z. Bilut-Homplewiocz, W. Czachura, M. Smykała (eds.). Lingwistyka tekstu w Polsce $i$ w Niemczech. Wrocław: Oficyna Wydaw, Atut.

Genette, G. (1997). Paratexts. Thresholds of interpretation. Cambridge: Cambridge Univ. Press.

Gnoli, C.; Ridi, R. (2014). Unified Theory of Information, hypertextuality and levels of reality. Journal of Documentation, 70(3), 443-460.

Godbold, N. (2006). Beyond information seeking: towards a general model of information behavior. Information Research [online], 11(4), [21.10.2015], http://www.informationr.net/ir/11-4/ paper269.html. 
Gradman, S. (2014). From containers to content to context. The changing role of libraries in eScience and eScholarship. Journal of Documentation, 70(2), 241-260.

Kock, N. (2009). Information systems theorizing based on evolutionary psychology: an interdisciplinary review and theory integration framework. MIS Quarterly, 33(2), 395-418.

Latham, K. (2014). Experiencing documents. Journal of Documentation, 70(4), 544-561.

Lenartowicz, M. ed. (1986). Przepisy katalogowania ksiażek. Cz. 1. Opis bibliograficzny. Warszawa: Stow. Bibliotekarzy Polskich.

Martin, J. (2001). Language, register and genre. In: A. Burns, C. Coffin (eds.). Analysing English in a global context. London: Routledge, 149-166.

Miller, C. (1984). Genre as social action. Quarterly Journal of Speech 70(2), 151-167.

Moulaison, H.; Dykas, F.; Budd, J. (2014). Foucault, the author and intellectual debt: capturing the author-function through attributes, relationships and events in Knowledge Organization Systems. Knowledge Organization, 41(1), 30-43.

Orlikowski, W.; Yates, J. (1994). Genre repertoire: the structuring of communicative practices in organizations. Administrative Science Quarterly, 39(4), 541-574.

Pearson, D. (2009). The roots of reading comprehension instruction. In: S. Israel, G. Duffy (eds.) Handbook of research on reading comprehension. New York: Routledge, 3-31.

Rosenblatt, L. (1978). The reader, the text, the poem: the transactional theory of literacy work. Carbondale: Southern Illinois University Press.

Rosenblatt, L. (1988). Writing and reading: the transactional theory. Technical Report no. 416. Champaign: Univ. of Illinois at Urbana-Champaign.

Rosenblatt, L. (1993). The transactional theory: against dualisms. College English, 55(4), 377-386.

Rosenblatt, L. (1994). The transactional theory of reading and writing. In: R. Rudell, M. Rudell, H. Singer (eds.) Theoretical models and processes of reading. Newark: Intern. Reading Assoc., 1057-1092.

Roszkowski, M. (2015). Kartoteki nazw osobowych w środowisku sieciowym. Biuletyn EBIB [online], 7(160), [7.12.2015], http://open.ebib.pl/ojs/index.php/ebib/article/view/380/551

Smagorinsky, P. (2001). If meaning is constructed, what is it made from? Toward a cultural theory of reading. Review of Educational Research, 71(1), 133-169.

Smiraglia, R. (2002). The progress of theory in knowledge organization. Library Trends, 50(3), 330-349.

Sosińska-Kalata, B. (1999). Modele organinzacji wiedzy w systemach wyszukiwania informacji o dokumentach. Warszawa: Wydaw. SBP.

Thellefsen, M.; Thellefsen, T.; Sørensen, B. (2015). The fallacy of the cognitive free fall in communication metaphor: a semiotic analysis. Library Trends, 63(3), 512-527.

Tomasello, M. (2015). Historia naturalna ludzkiego myślenia. Warszawa: Copernicus Center Press.

Tracey, D.; Morrow, L. (2012). Lenses on reading. An introduction to theories and models. 2nd ed. New York, London: The Guilford Press.

Tredinnick, L. (2007). Post-structuralism, hypertext, and the World Wide Web. Aslib Proc., 59(2), 169-186.

Vellucci, S. (1998). Bibliographic relationships. In: J. Weihs (ed.) The principles and future of AACR. Proc. of the Internat. Conference on the Principles and Future Development of AACR. Toronto, October, 23-25, 1997. Ottawa: Canadian Library Assoc., 105-146.

Vaughan, M.; Dillon, A. (1998). The role of genre in shaping our understanding of digital documents. In: Proc. of 61st Annual Meeting of the ASIS. Medford: Information Today Inc., 559-566.

Wierzbicka, A. (1983). Genry mowy. In: T. Dobrzyńska, E. Janus (eds.) Tekst i zdanie: zbiór studiów. Wrocław: Zakład Narodowy im. Ossolińskich, p. 125-137.

Wilson, E. (2011). Konsiliencja. Jedność wiedzy. Poznań: Zysk i S-ka.

Wilson, T. (1999). Models in information behavior research. Journal of Documentation, 55(3), 249-270. Wojciechowski, J. (2014). Biblioteki w nowym otoczeniu. Warszawa: Wydaw. SBP. 
Zhang, P.; Soergel, D. (2014). Towards a comprehensive model of the cognitive process and mechanisms of individual sensemaking. Journal of the ASIST, 65(9), 1733-1756.

\title{
Transakcyjna teoria czytania w organizacji informacji
}

\begin{abstract}
Abstrakt:
Cel/teza: Celem artykułu jest przedstawienie niektórych możliwości zastosowania teorii gatunków tekstu, teorii transakcji oraz teorii schematów poznawczych w organizacji informacji. Gatunek tekstu traktować należy jako schemat mentalny powstający i rozpowszechniany w wyniku powtarzalnych transakcji z tekstem. Opis (rekord) bibliograficzny/katalogowy traktować można jak tekst określonego gatunku, co pozwala na badanie jego społecznych transakcji zarówno pomiędzy tekstem i autorem (organizatorem informacji, bibliotekarzem), jak również pomiędzy tekstem i odbiorcą (użytkownikiem systemu informacyjnego, biblioteki). Badania te mogą być przydatne m.in. dla opisu zmian transakcji związanych ze zmianami technologii informacyjnych.

Metody badań: W artykule przedstawiono zmiany w transakcjach organizacji informacji wynikających ze stosowania nowych technologii informacyjnych, a więc zamiany tekstów opisów bibliograficznych/katalogowych w cybertekst, a ich gatunków w cybergatunki. W artykule opis tych zmian przeprowadzono na podstawie głównie transakcji wyszukiwania według dwóch elementów tekstów opisów: nazw autorów i tytułów dzieł w różnych środowiskach technologicznych.

Wyniki i wnioski: Zmiany w technologiach stosowanych w organizacji informacji prowadzą do rozwoju i wzbogacania transakcji użytkownika z tekstem opisu w celu zwiększenia możliwości wyszukiwawczych i uproszczenia sposobów realizacji transakcji.

Oryginalność/wartość poznawcza: Podstawą przedstawionych koncepcji są teorie schematów poznawczych (konstruktywizm), gatunków tekstów (Miller oraz Andersen) oraz transakcji (Dewey, Rosenblatt) zastosowane do analizy opisów bibliograficznych (katalogowych), traktowanych jako teksty tworzone w określonej konwencji, powstającej jako efekt powtarzalnych transakcji między organizatorem informacji i jej użytkownikiem. Taki punkt widzenia pozwala na właściwe umiejscowienie tych tekstów wśród tekstów funkcjonujących w dyskursie naukowym.
\end{abstract}

\section{Słowa kluczowe}

Organizacja informacji. Teoria gatunków tekstu. Transakcyjna teoria czytania.

Dr hab. MAREK NAHOTKO is Associate Professor at the Institute of Information and Library Science at Jagiellonian University, specializing in the issues of metadata for electronic documents and the use of the Internet in scientific communication and information services. He published books: Komunikacja naukowa w środowisku cyfrowym [Scientific communication in digital environment] (Warsaw, 2010), Naukowe czasopisma elektroniczne [Electronic research journals] (Warsaw, 2007), Opis dokumentów elektronicznych. Teoretyczny model i możliwości jego aplikacji [Description of electronic documents. The theoretical model and the possibilities of its application] (Cracow, 2006), Metadane : sposób na uporzadkowanie Internetu [Metadata: how to organize the Internet] (Cracow, 2004) and numerous articles, among others in journals Przeglad Biblioteczny [Library Review], Zagadnienia Informacji Naukowej [Issues in Information Science] and Biuletyn EBIB [EBIB Bulletin].

Contact to the Author:

marek.nahotko@uj.edu.pl

Institute of Information and Library Science

ul. prof. Stanistawa Łojasiewicza 4

30-348 Kraków, Poland 